DOI: $10.2478 /$ ausfm-2014-0008

\title{
Mothers, Stepmoms and the Brave New Family. Intercultural Remake and Melodrama: an Analysis of the American Stepmom and its Bollywood Remake
}

\author{
Natália Fábics \\ Eötvös Loránd University (Budapest, Hungary) \\ E-mail: fabics@t-email.hu
}

\begin{abstract}
The Bollywood remake of the American weepie Stepmom (Chris Columbus, 1998) is a fine and rather recent example of the intercultural remake phenomenon, a study topic that is gaining more and more attention. With the aim of suggesting conclusions generally applicable to intercultural remakes, starting from the genre, through characterization, film style and narrative, the present paper examines the remake process in the case of We Are Family (Siddharth Malhotra, 2010) and Stepmom.
\end{abstract}

Keywords: intercultural remake, melodrama, Bollywood, Chris Columbus: Stepmom (1998), Siddharth Malhotra: We Are Family (2010).

As cinemas around the world are more and more filled with remakes, be it inter- or intracultural ones, the remake phenomenon is also becoming a favourite of film study researches and publications. Entire books are filled with thorough analysis - for example the American remakes of French films, ${ }^{1}$ or that of Japanese horrors, ${ }^{2}$ while a few studies prepared with the aim of building the foundations of the theoretical background of remakes have also been published. $^{3}$ But these works have dealt only with one direction of the phenomenon - the American remakes of films first created in other cultures,

1 Lucy Mazdon: Encore Hollywood: Remaking French Cinema (2008), or several chapters of Forrest, Jennifer (ed.), Koos, Leonard R. (ed.): Dead Ringers: The Remake in Theory and Practice.

2 Books about Japanese horror movies usually discuss the remake phenomenon, for example Jay McRoy's Japanese Horror Cinema (2005) and Nightmare Japan Contemporary Japanese Horror Cinema (2008).

3 For example Play it again Sam: Retakes on Remakes (1998), Dead Ringers: The Remake in Theory and Practice (2001), and the most recent in the line is Film Remakes (2005) by Constantine Verevis. 
namely how American, most likely Hollywood filmmakers remake European (mostly French) and Asian originals.

While a lot can be said about remakes we should not forget that it is fundamentally a legal concept, i.e. the filmmaker buys the rights to reshoot the original. In the case of Bollywood movies even this aspect brings up exciting issues as until recently the average Bollywood filmmaker would never have thought of paying for remake rights (neither to Hollywood, nor to Bollywood, or to anyone else). In a film culture where film and other quotations, intertexts, redrafting plots, playing with earlier works of actors, directors and even choreographers is everyday practice, an indefeasible characteristic of Bollywood movies, it is hard to explain that in other parts of the world huge amounts are paid for it. Nevertheless, as a result of globalization, Bollywood filmmakers have started paying for remake rights. In fact, We Are Family (Siddharth Malhotra, 2010) was a pioneer in this respect. Karan Johar, one of the producers acquired the remake rights of the American original, so remake as a legal concept was clarified in this case.

\section{Genre and Style}

"The nuclear, middle-class family, the clearest representation of America's patriarchal and bourgeois social order" (Schatz 1991, 152) became a favourite of American melodramas back in the fifties. World War II and the Korean War were at the core of social changes, shifts in power relations within the family (employment of women, questioning the raison d'être of traditional male attitudes, suburbanization, generational conflicts, and so on). The genre rather popular in American filmmaking right from its early days ${ }^{4}$ reflected on these changes and created world-famous, now classic pieces like Douglas Sirk's All That Heaven Allows (1955), Written on the Wind (1956) and Imitation of Life (1959), or from another great director of melodramas, Vincent Minelli, Cobweb (1955), Some Came Running (1958), Home from the Hill (1960), but further classics can also be listed here, such as Giant (Stevens, 1956), Rebel Without a Cause (Ray, 1955), Cat on a Hot Tin Roof (Brooks, 1958), and so on. Despite periodic revivals during and even after the sixties, the era of such classic

4 Just to mention some of the most prominent figures: D. W. Griffith widely considered to be the most outstanding director of silent era melodramas; moving into the talking picture era, we have Frank Borzage, John Stahl, the German Max Ophuls, and arriving to the most acclaimed melodrama directors of film history, it is Vincent Minelli and Douglas Sirk whose works take us into the world of fifties' family melodramas. 
Hollywood melodramas is over (Schatz 1991) and nowadays the genre very rarely appears in its pure form. ${ }^{5}$

Starting in the 1970s, film critics and historians have developed the generic typology of Hollywood melodramas. On the level of the narrative a fundamental characteristic is the replacement of actions with emotions, the plot is superficial, its typical characters are weak male and dominant female figures, while the film style is essentially determined by symbolic mise-en-scène. In his critical standard of the genre outlined in Hollywood Genres, ${ }^{6}$ published in 1981, Thomas Schatz collects the following characteristics: victimized protagonist; the generational conflicts of the middle-class family are in the forefront of the story; the home is the centre of social interactions; symptoms of the Freudian repression appear; the viewer continuously compares his/her own values, experiences, the conflicts of his/her life with those of the hero(es); the viewer sympathizes with the central, victimized character; and in accordance with classical Hollywood traditions the film is closed with a sudden and/or marvellous happy end. ${ }^{7}$

All these characteristics are certainly not unknown in Bollywood cinema. Yet similarly immaculate versions are unexampled and not even the genre purification experienced in the past few years has excelled in melodramas. The only one I have met is Sanjay Leela Bhansali's Guzaarish (2010). The film, which tells the story of a paralysed, once very famous and very attractive magician fighting for euthanasia and saying farewell to the spectacularly shot beauties of life would have stood its ground even in the heyday of Hollywood melodramas. Bollywood masala movies starve for melodrama's bittersweet taste, but must mix in other genres as melodrama in itself seems to be indigestible for the Indian stomach.

I compare the genre characteristics of Stepmom and We Are Family on the basis of Thomas Schatz's melodrama typology summarized above and examine

5 Some of the contemporary representatives of classic Hollywood melodramas have received numerous prestigious awards and become widely known around the globe, like Far from Heaven (Haynes, 2002), or Brokeback Mountain (Ang Lee, 2005), while a popular version of mixed genres is melodrama meeting romantic comedy, for example Punch-Drunk Love (Anderson, 2002), a rom-com playing around with male melodrama characteristics, or The Family Stone (Bezucha, 2005), a film maneuvering amongst elements of family melodramas and romantic comedies.

6 Originally published in 1981, The Family Melodrama chapter was republished in 1991 in Imitations of Life edited by Marcia Landy. I used the 1991 text for the present paper.

7 Source: seminar led by László Strausz under the title Family and Ideology: Melodrama in American Cinema (original Hungarian title: Család és ideológia: A melodráma az amerikai filmben) at Eötvös Loránd University, Budapest, Department of Film Studies, Autumn Semester, 2010. 
whether both films can be handled as melodramas, or the Bollywood remake is more in line with masala cinema traditions. As Schatz's melodrama definition practically looks at every basic element of film analysis I also compare the two films by searching for the points where the Bollywood remake differs from the original or happens to take over certain elements.

\section{Strong Women, Weak Men}

As for characters, the American original is undoubtedly the film of the two adult women where the father at his most appears as a know-nothing servant to the emotional hardships and development of the dominant women. For most part of the movie he is not even present and by that I do not mean time in the film only, but the turning points, more precisely the emotional turning points of the plot as well. The children - even though the script gives them room for presenting more detailed, layered characters - follow their father and the Hollywood work description of supporting actors in, well, supporting the two female heroes of the story.

In this respect, We Are Family moves away from the American recipe. Bollywood cinema does not practically know female protagonists and it is not only scripts where they can not take the lead. An actress can never reach the star status of her male colleagues, and a woman has no chance of ever being listed among the best paid Bollywood superstars. Even if we undoubtedly talk about a women's movie here, the makers of We Are Family had no chance of leaving this tradition behind completely and they advanced the male hero to the level of, or somewhat even above the two female characters. Aman, the father is a well-developed character. He is present at every turning point of the plot, what is more he is the determinant force behind resolutions, in most cases the one putting an end to conflicts between the other characters. For example, when the stepmom-to-be, Shreya loses the younger girl, Anjali in a park, it is Aman stating that in the future she cannot look after the children on her own. He even sticks up for his ex-wife: "Let Maya handle the kids... She knows about the kids... She is a good mom!”, then leaves his fiancé. In Stepmom this would be unimaginable. In a similar situation when Isabel, the American stepmom-tobe loses Ben, the smaller kid, the father for a few vague moments seems to take his ex-wife's side, but by the end of the scene that steadiness vanishes and he is happily lost in a passionate kiss with his girlfriend. He would never stick up for his ex-wife against his girl-friend/fiancé. For that matter, he does not even get into situations where either his ex-wife or his fiancé would need his support or even his opinion. The female characters fight their own battles completely on 
their own, always excluding the male. An important turning point of the plot is when the family finds out about the lethal illness of the mother. When learning about the fatality of her illness, Maya, the mother in We Are Family makes no bones about telling it to her ex-husband right away, who does not simply help her, but breaks up with his love and moves back with his family. At the same point of Stepmom the ex-husband is - again - not present. What is more Isabel, the stepmom-to-be is the one first informed about the illness.

Dozens of similar examples could be listed to present the differences between the characterization of the two films, but the composition of the family portrait taken towards the end is of symbolic value. In the portrait of Stepmom the husband is in the background, behind the children. He appears to be the same height as they are, while the two women occupy half of the photo. [Fig. 1.] As if that was not enough, the actual closing frame is a closer shot of the old and the new mother slowly dissolving into the family portrait. [Fig. 2.] On the other hand, the similar shot of We Are Family is a family portrait with the father overtopping the family (including the new mother, as well). Unlike in the original film, the shot here is actually shown as a picture - first through the lens of the camera, then framed and placed on the wall as a stationary part of the decor in the home of the new family complete with the new mother. [Figs. 3-4.]

\section{Overflow of Style}

Almost ten years before the above mentioned study by Schatz was published, based on the analysis of about a dozen films, Elsaesser wrote his acclaimed essay titled Tales of Sound and Fury: Observations on the Family Melodrama, ${ }^{8}$ in which he underlines the outstanding importance of mise-en-scène in the films of the genre. Basically he states that as in melodramas everything happens "inside," the dramatic conflict is elaborated through the mise-en-scène, thus costumes, sets, colours, music, gestures, composition, and so on, become more important than intellectual content and story-telling.

Every bit of Stepmom follows on this Hollywood melodrama tradition. The film takes place in the spacious areas of the suburbs, in the living environs of the children and their mother (home, school, park), but even the flat of the father otherwise living in New York with his girl-friend meets all criteria of the suburban middle-class family home (huge, light kitchen, perfectly decorated vast rooms for the kids). Everything elaborately detailed, filled with objects

8 The essay was first published in 1972, for the present study I used its 1991 republished version from Imitations of Life edited by Marcia Landy. 
typical of the American bourgeois family complete with the figure of the mother wearing clothes displaying colours fading into the surroundings. [Figs. 5-6.] It is this warm world of autumn shades that Isabel's slim and tall figure intrudes as a black sword cutting through the matching colours and shapes, while in her own home she is just as pastel as any suburban mother should be. [Figs. 7-10.]

Hundreds of objects, toys, kitchen tools, pictures, mirrors, the symbols of middle-class life are spread all around the always perfectly balanced compositions. Slow camera movements introduce the spaces, crane shots accompanied by assertive musical scores lead us into the world of the American bourgeois, while each and every frame is flawlessly photographed.

In We Are Family the environment is in line with the milieu of Indian middle-class living in the West as it is usually represented in contemporary Bollywood cinema (for example the children's pastel-flashy huge room decorated as a plastic Barbie castle complete with a double bed for kids (!), in which they regularly fall asleep together), as well as with social and cultural traditions (for example there is no separate room for the children, not even toys scattered around in the father's home as the child does not belong to the father who left his family, but only to the mother and the original family home). However, it is not exaggerated, even a bit meagre compared to the usual stagelike interiors of Bollywood mainstream. The same applies to the immaculate cinematography and the perfectly balanced compositions. While Stepmom in this respect is again rather different from contemporary Hollywood movies, We Are Family has nothing to differ from. We could even say that Bollywood film style is actually a warm, welcoming environment for American melodrama mise-en-scène, thus there is not much to do when shooting the remake. Simply handle it as another mainstream Bollywood film.

Music is another favourite element of American melodramas and it is not the least different in the case of Stepmom either (for example the ever returning song Ain't no mountain high enough or the musical score loudly barging in whenever we are supposed to feel the drama). Yet in the case of the Bollywood remake it is a very interesting question that even leads us into the world of masala films.

We Are Family is full of music, sound effects are used to stress dramatic moments, and at first it is hard to differentiate it from Bollywood cinema's all familiar devotion to music. But if we take a closer look it is clearly something very, very different. An inevitable characteristic of the musical inserts of masala films is that they break the flow of the plot, in several cases bringing the world of dreams and desires that can otherwise never come true - mostly due to social and cultural reasons - into the text of the film, stressing emotional culmination, singing and dancing instead of saying and doing. Bollywood cinema also has an 
incurable affection for attaching certain tunes to a given character or to a certain emotional state. If we look for these characteristics in We Are Family we find rather interesting solutions.

Musical inserts break the flow of the film at five points. The first of these is the opening sequence itself, when Shreya and Aman (i.e. stepmom-to-be and father) appear as young lovers expressing their love in a montage sequence of driving a car (convertible, of course) in spectacular surroundings, passing time by the sea including walking, hugging, eating, reading, taking photos of each other, and feeding birds. All this accompanied by a love ballad performed as a duet. But they neither dance, nor sing, thus the scene moves away from traditional Bollywood musical inserts. Another similar montage sequence is used when Aman deicides to leave his fiancé and moves in with his (former) family because of the fatal illness of the ex-wife. At this undoubtedly important emotional turning point the role of the musical insert is to present an emotional situation that is beyond words - it is only his sense of duty that makes Aman nurse his wife. Love ties him to Shreya, while the vain hope of becoming a couple with Aman arises again in the ex-wife. The third insert of this type again - intermits the flow of the story at the point where Maya collapses and is taken to hospital, and everyone knows that she is dying. The song and the montage sequence in fact interprets the emotional state of the characters.

The two other musical inserts completely diverge from these three, albeit in different ways. The only, more or less Bollywood masala style scene takes place when all characters live together in the same house and go out to a karaoke bar. The establishment of the situation is absolutely down-to-earth, is in line with the plot and the real world, as, after all, there is nothing unusual about singing in a karaoke bar. Not even an emotional or any other turning point is around. The casus belli is Shreya telling Maya that she is always too tense, she might not even know how to have fun. Maya protects her fun-loving nature by swinging onto the stage and a musical insert conceived in the traditions of masala cinema submerges the screen. A chorus line dressed in clothes evoking the world of cabarets emerges led by the otherwise completely average, middleclass characters, who all of a sudden turn into eye-catching show stars singing and dancing rock and roll. [Figs. 11-14.]

The fifth and within the film the last musical insert is again very different. It is the only one that completely takes us away from the space and the time of the film. The washed out Maya sitting in a wheelchair is pushed into the spotlight by Aman. Then an emotional song starts as in a stage-like space surrounded by hundreds of light chains she watches the photos of her past family life projected on giant screens with tears in her eyes while her children and ex-husband are sobbingly hugging her. And Shreya is the VJ; and the photographer. And it all 
ends with the family photograph discussed earlier. The function of the scene in the film is to lead us into the future, to the wedding day of the older daughter from the scenes of Maya saying good-bye to the members of her family and to Shreya, to whom Maya hands over her wedding jewellery asking her to adorn the older daughter with them when the time of her wedding-day arrives. So she practically hands over her motherly duties to the new wife. All in all, while not showcasing the singing and dancing musical insert familiar from masala movies it brings in another characteristic by breaking away from the reality of the film's space and time, and can be interpreted as the bollywoodized screening of Maya's funeral. [Figs. 15-16.]

In my opinion, these musical inserts shift the film in the direction of the world of masalas, but not by a long shot does it get there. I think that a filmmaker working in the Bollywood movie scene cannot - in case he/she wants to make a movie marketable in India, too - completely break away from that cinematic tradition. Something familiar, something old must be shown to the audience and as a reward he or she can, for example, discuss contemporary cultural or social issues that are considered taboo by many. Music, song, and dance are still inevitable to reach the audience of Bollywood movies. We Are Family is not the only one transforming this tradition through striving to edit musical montage sequences more in the style of Hollywood mainstream, or contextualizing songs and musical inserts, even trying to make them more realistic (for instance instead of the usual playback it really is the actor who sings, like in Abhishek Kapoor's 2008 Rock On!! or Zoya Akhtar's 2011 Zindagi Na Milegi Dobara), and so on.

If we also consider that - as discussed earlier - music plays a key role in the mise-en-scène of American melodramas, similarly to the above analysed scenery and cinematography, in the case of music we could also suggest that the world of Bollywood cinema is a natural environment for classic American melodrama and not much needs to be altered to produce a piece familiar and acceptable both for Western and Indian audiences.

\section{Narrative and Abruptness}

Fundamentally different from the classical Hollywood narrative structure, from its inevitable linearity, its cause-and-effect chain, the Bollywood narrative developed occluded from and in parallel with Hollywood cinema. Its abruptness roots in the already discussed musical inserts, but also in the intermissions cutting the films in two parts and the obligate lapses, holes in the plot caused by the necessity of meeting the requirements of censorship (cf. 
Vincze 2007, 20-23). The mixed tone dragging the viewer suddenly from one genre to the other further strengthens the sense of abruptness, and also the characteristic described by Teréz Vincze (2007) in her study published in the Bollywood issue of Metropolis that Bollywood cinema is more the cinema of attractions than of storytelling, it above all strives to hold its audience visually spellbound.

Stepmom perfectly conforms to the conventions of classical Hollywood narratives that divide the plot into three acts; the first one being the set-up (Field 2005), or exposition (see Pramaggiore and Wallis 2008) that prepares the film's central conflict and is followed by the second act, called confrontation, then by the third act, usually referred to as the resolution (see Field 2005). According to Bordwell (1985), the latter can be divided into two more parts, the second, very last few minutes being the epilogue. Each act is separated by turning points (altogether two) that split the film in a 25-50-25 percent ratio. Reconsidering this break-up, Kristin Thompson created the 4-part structure suggesting that there is actually a so-called critical turning point in the very middle of the film. At the first turning point the balance of the world as we got to know it in the first act collapses and then comes the complicating action leading us to Thompson's critical turning point, which is the starting point of our protagonist's fights to achieve a certain goal. This struggle finally takes us to the climax followed by the resolution and the epilogue. In this approach, the four parts are more or less of the same length (see Pramaggiore and Wallis 2008).

Stepmom precisely follows this four-act model. In the 30th minute $(25 \%$ of the film) we can see the fight between Jackie (the mother) and Isabel (father's fiancé) at the police station after Isabel lost Ben (the son) in the park. From this point on the two female characters' impiteous crusade is at the core of the plot. Then it is in the 60th minute that Jackie is forced to directly ask for Isabel's help - from this point on the motivating theme of the plot is Jackie's fatal illness. In the 90th minute the two women's relationship consolidates when Jackie arrives back from a medical treatment in Los Angeles to be welcomed by her room decorated with life-sized prints of her children's photographs prepared by Isabel. From this point on, consigning maternal roles is in the centre of the film leading to the Christmas scene of the last minutes giving us Bordwell's epilogue.

There is not much trace of this meticulously developed classical Hollywood narrative in We Are Family. Conflicts unexpectedly slap the viewer in the face, important character decisions of significant effect on the flow of events are not prepared either on the level of the plot, or on the level of characterization, while certain motifs - for example the stepmom-witch parallel - are overemphasised. At the same time, key elements of Stepmom are used in the Bollywood version, but mostly in different parts of the script, appearing 
unexpectedly, seemingly out of context. The premise is the same: divorced parents, mother raising the children, father wants to remarry so tries to get the children and his fiancé together, and the failing fraternization process gathers momentum thanks to the fatal illness of the mother. The end is also the same, the mother consigns her role to the stepmom. Key motifs, characters are also more or less similar: charming kid committed to magic, yet of rather rational thinking and friendly (in the Bollywood version it is divided into two characters), the unbearably selfish and rude older sister, the workaholic father, the clockwork-perfect homemaker mother, the young, fashionable girlfriend. But all these thread together according to the rules of Bollywood narratives.

A script conceived in terms of abruptness, a plot interrupted with musical inserts and an intermission is further dishevelled by elements taken from different genres. When surveying the key characteristics of melodramas I reached the conclusion that Bollywood cinema is essentially a welcoming environment for melodrama and stated that We Are Family took over the genre framework of Stepmom. Yet the scheme is not at all that simple. The dominating melodrama elements are completed with elements from other genres to satisfy the special expectations of Indian audiences. From time to time we feel that we are watching a romantic comedy (the montage sequence of the opening scene), a family comedy (food fight, Shreya not wanting to give breakfast), or a children's film (every scene centred around the younger daughter evokes the world of children's films). I am not trying to suggest that there are no scenes in Stepmom making the audience smile (for example when the daughter clears up her love-life crisis with the help of Isabel), but these are only short moments and never make us laugh wholeheartedly. We Are Family patently aims at meeting the requirements of Indian audiences: no matter what the film is about, from time to time it has to have comedy elements, while it also has to function as a family movie. Without these binding rules, on the other hand, Stepmom is a real, traditional weepie.

\section{Different Culture, Different Emotions?}

It is very difficult, or even impossible to define the point from which we can consider a film the remake of a previous one. I think the generally accepted approach suggesting that the remake uses the key elements and motifs of the earlier one's plot can serve as a starting point, but it is only with the thorough comparison of the actual films that we can come to a decision. It is an especially complex issue in the case of intercultural remakes, especially if we consider remakes between Asian and Western cultures. The differences in 
cultural conventions, conflicts and problems of the given societies touch a certain level of the films that is not necessarily revealed by film analysis alone. The question cannot be examined without knowing the two cultural and social environments, as well as their cinematic traditions and taking into consideration the differences between them.

As noted earlier in my essay, a significant, if not the most significant characteristic of melodramas is that emotion replaces action as the defining plot-development device. The physical activity of the protagonist is superseded by emotional activity, thus a key element of remakes, namely the adoption of the plot is difficult to examine. For example, however important the mother's illness is in both movies, it is the emotional reactions of the characters to the situation that conduct the plot, not, let us say, the turning points of the treatment or a marvellous recovery. Filming emotions raises the question of what emotions are important and what emotions are allowed to be felt in a given culture or society at a given time and, in parallel with that, what current social issues the members of the society must (should) learn to handle even against visceral feelings. As an example, the father of the American version is very helpful and supportive when he learns about the illness of his ex-wife. Still, the idea of him moving back with his family would be out of question, while in the Bollywood version not moving back would be out of question. This decision fundamentally affects the flow of action, but my question is this: in the world of melodramas, where emotions rather than actions are in the works is it really important who moves where? The concept of the nuclear family has been redefined dozens of times in western cultures and we no longer think about what it actually means in practice. The remarriage of divorcees is an everyday routine, the ex-husband does not leave his fiancé to nurse his dying ex-wife and does not for the world move the new woman in with the old one. Unlike in Indian culture, where the nuclear family tries to fight the storms of modern times with its immovably stable definition, the man has to move all those involved under the same roof. According to We Are Family, a feasible solution would be to turn the former and present love of his life into caring, loving sisters. All in all, even though the plot leads us into different directions on the level of actions, the same thing happens on the level of emotions: living and handling a very similar private life situation in a way defined by cultural and social expectations. Even the predictable end, the death of the mother is the same, meaning that - independently from cultural background - the most optimal resolution, also reconstituting the beau ideal of patriarchal societies' nuclear bourgeois family, is if the other female character, who has after all proven herself in several battles, and even satisfies daddy intellectually, emotionally and sexually, becomes the new mommy. 
In an interview debut director Sidharth Malhotra said about We Are Family that it is not a remake, but an adaptation, an idea further stressed by the actors explaining that they had their own artistic approaches in playing the characters. ${ }^{9}$ While the generally accepted approach that adaptation is inevitably an intermedia process that is incomprehensible in the case of a film based on another film, on the basis of the two films' comparative analysis it is more understandable what they had in mind: human emotions resulting from changes in family relations were here "adapted" from Hollywood to Bollywood. It still does not change the fact that We Are Family is, not only from a legal but also from a film study point of view, another classic of the intercultural remake phenomenon.

\section{References}

Bordwell, David. 1985. The Classical Hollywood Style, 1917-1960. In The Classical Hollywood Cinema. Film Style and Mode of Production to 1960, eds. David Bordwell, Janet Staigner and Kristin Thompson, 1-84. London Melbourne and Henley: Routledge \& Kegan Paul.

Elsaesser, Thomas. 1991. Tales of Sound and Fury: Observations on the Family Melodrama. In Imitations of Life, ed. Marcia Landy. Detroit: Wayne State University Press.

Field, Syd. 2005. Screenplay, The Foundations of Screenwriting. New York: Delta.

Forrest, Jennifer and Leonard R. Koos, eds. 2001. Dead Ringers: The Remake in Theory and Practice. New York: State University of New York Press.

Horton, Andrew and Stuart Y. McDougal, eds. 1998. Play it again Sam: Retakes on Remakes. London: University of California Press.

Mazdon, Lucy. 2008. Encore Hollywood: Remaking French Cinema. London: British Film Institute.

McRoy, Jay. 2005. Japanese Horror Cinema. Honolulu: University of Hawaii Press.

McRoy, Jay. 2008. Nightmare Japan - Contemporary Japanese Horror Cinema. Amsterdam - New York: Rodopi B.V.

9 He explained at a promotional press conference of We Are Family on August 25, th 2010: "This film is not the official remake of Stepmom, we have taken the rights but I will not say it is a remake I will say it is an adaptation because remake means the total copy of the film." He even added an example supporting his approach, namely that in the Bollywood version the characters live in the same house, which did not happen in the original film. Source: http://ww.smashits.com/we-are-family-is-not-aremake-siddharth/video-watch-18185.html. 
Pramaggiore, Maria and Tom Wallis. 2008. Film: A Critical Introduction. London: Laurence King Publishing Ltd.

Schatz, Thomas. 1991. The Family Melodrama. In Imitations of Life, ed. Marcia Landy, 148-167. Detroit: Wayne State University Press.

Verevis, Constantine. 2005. Film Remakes. Edinburgh: Edinburgh University Press.

Vincze, Teréz. 2007. Felfedezőút a filmvilág szubkontinensén. [Exploring the Film World's Subcontinent] Metropolis, no. 1: 8-23.

Wee, Valerie. 2001. Visual Aesthetics and Ways of Seeing: Comparing Ringu and The Ring. Cinema Journal, no. 2: 41-60.

\section{List of Figures}

Figures 1-2. Family portrait at the end of Stepmom and the actual closing frame of the film displaying a closer shot of the old and the new mother.
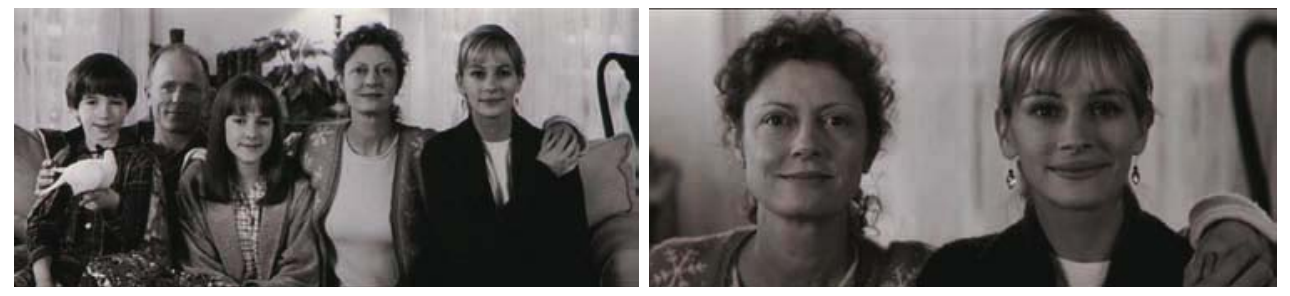

Figures 3-4. The family portrait at the end of We Are Family is a family portrait that is actually shown as a picture in the film - first through the lens of the camera, then framed and placed on the wall.
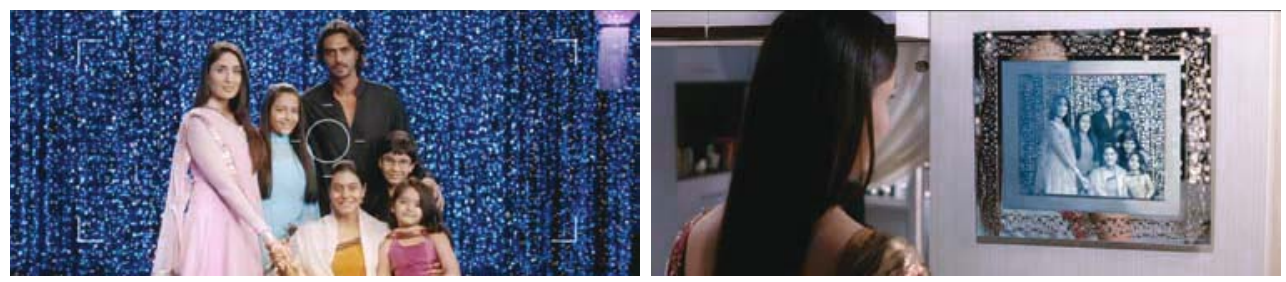
Figure 5-6. The mother in Stepmom melts into the elaborately detailed suburban environment filled with objects typical of the American bourgeois family.
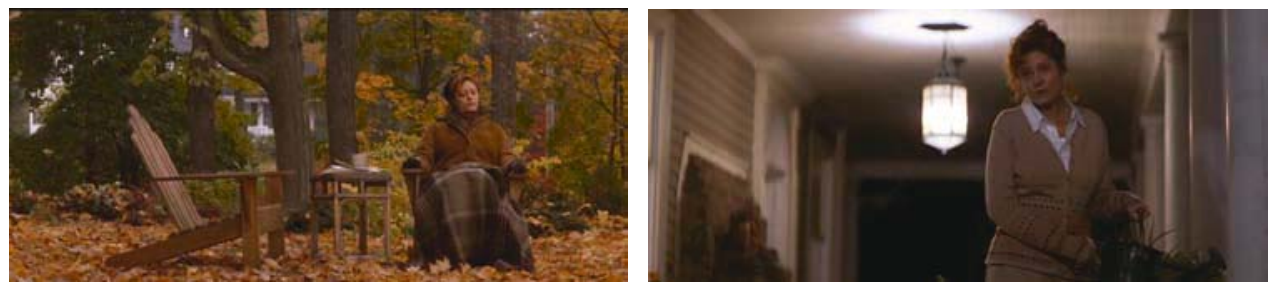

Figures 7-10. The girlfriend of the father in Stepmom intrudes the world of the once traditional bourgeois family as a black sword cutting through the matching colours and shapes. At the same time, in her own home she blends in just like any suburban mother.
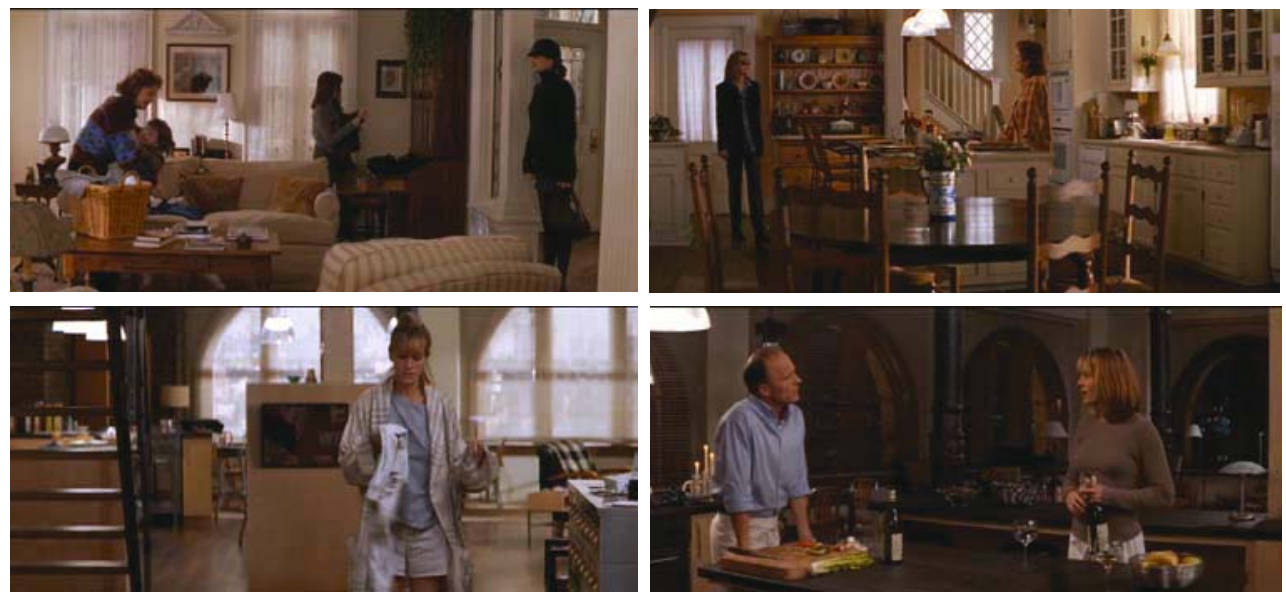

Figures 11-14. A more or less Bollywood masala style scene mixing cabaret, as well as rock and roll elements from We Are Family: the average, middle-class characters turn into eye-catching show stars singing and dancing rock and roll with a professional chorus line.
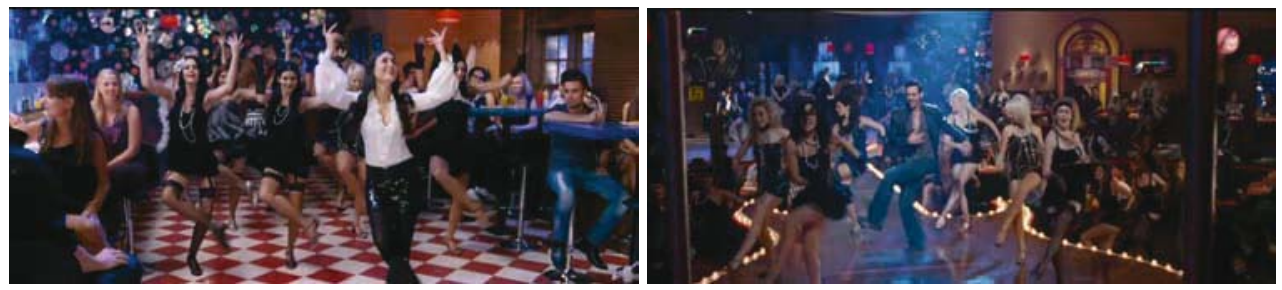

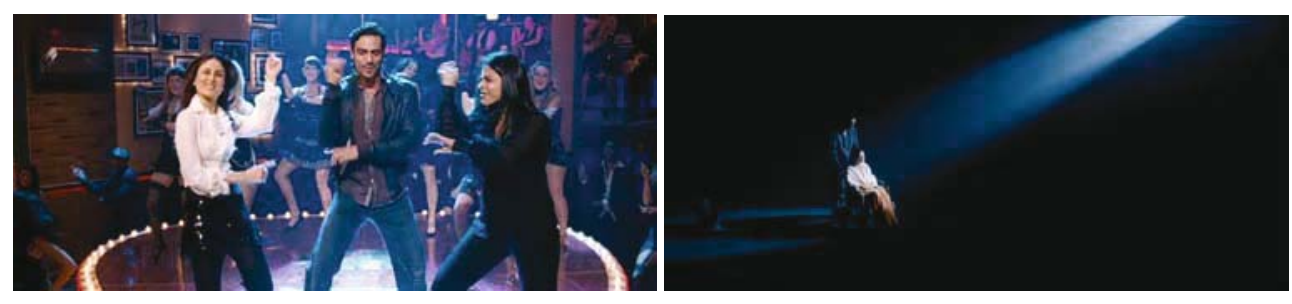

Figures 15-16. The death of the mother in We Are Family á la Bollywood.

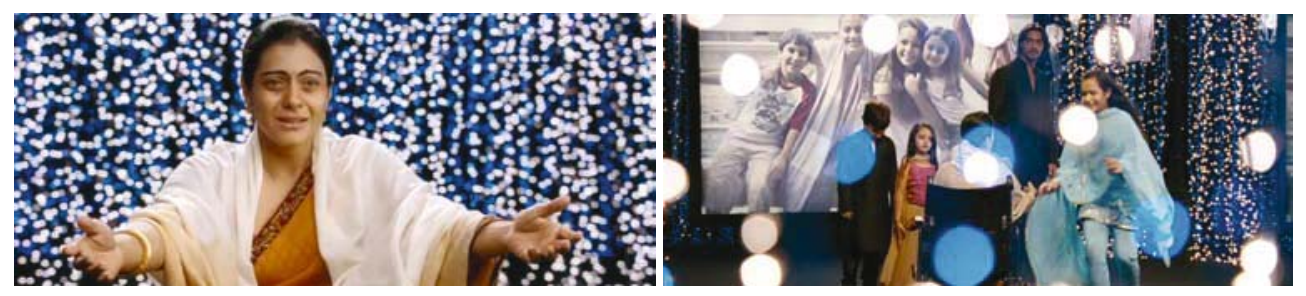

